daily African diet. Studies include laboratory investigations into the composition of foodstuffs and research on methods of distribution, particularly to vulnerable groups of the population, such as school children in French West Africa and Uganda and miners in the Union of South Africa. The aim of this research is to provide complementary or supplementary food for those who need it most.

In French West Africa the creation of ORANA (Institute for Nutrition and Food Research in Africa) and its achievements in the pilot village of Popenguiné, have resulted in a considerable decrease in the infant mortality rate, and emergency measures have been taken against the spread of 'kwashiorkor'. Research is also being carried out in Nigeria, the Belgian Congo, Uganda, and the Union of South Africa.

\title{
Meeting of European and African experts at Strasbourg
}

A GRoup of Europeans and Africans met at the Maison de l'Europe in Strasbourg in the summer to study suitable methods of promoting economic and social development in Africa.

The members of the group, who have been chosen because of their knowledge and experience and whose opinions are their own and not necessarily those of their governments, are as follows: A. R. Bolamba (Belgian Congo), L. Bourgier de Carbon (France), C. Carbonnelle (Belgium), Arthur Gaitskell (United Kingdom), Alexis Kagame (Ruanda-Urundi), A. Lawrence (French Guinea), E. Miesch (German Federal Republic), Ceriani Sebregondi (Italy), Paul Rykens (Netherlands), O. Arikpo (Nigeria), Jules Ninine (French Cameroons), and Tshekedi Khama (Bechuanaland).

The aim of the group is to gather together a number of independent experts from the member countries of the Council of Europe (whether or not they have responsibilities in Africa) and African territories likely to be interested in the study of methods to promote economic and social development in Africa. The group should put forward suggestions to encourage and accelerate such development and to raise the standard of living of African peoples, in the interests of African as well as of European prosperity, by co-operation on an equal basis between African territories and the member countries of the Council of Europe.

\section{University Training for Community Development in Ghana}

THE Certificate Course in Social Studies at the University College of Ghana started in January 1956. It has been found that much of the resistance to community development met with arises from inadequate use of sociological and anthropological knowledge of the community it is hoped to develop. Nor is the need for community planning any less great in new towns and housing estates than in villages and rural areas. The syllabus for the Certificate Course therefore comprises social administration, the study of society (i.e. a representative group of African societies), political and administrative institutions, and social economics, psychology and philosophy. The aim of the course is to integrate theory and field work, for which the student is sent to an area which is new to him.

As this is the first experiment of its kind in Africa, considerable difficulties have been encountered, notably the language difficulties of Mass Education officers, and shortage of textbooks on the social service organization, social history, and social problems of Ghana. There is need for more adequate staffing and for research into such subjects as social psychology and social philosophy and for money to carry out these projects.

I See Africa, January 1957, pp. 79-80. 